\title{
International financial inclusion: Multidimensional determinants of access to saving and credit*
}

\author{
Lilianne Isabel Pavón Cuéllar ${ }^{1}$
}

\begin{abstract}
This work assesses quantitatively the determinants of two of the main indicators of financial inclusion: savings account ownership and credit access. Through the use of a dynamic panel, this work verifies that on the supply side, formal saving requires an infrastructure to access these services, as well as palliatives to the asymmetric information in the financial sector, while on the demand side, the education and the stability of income sources of its potential users are crucial. In order to move to a more comprehensive financial inclusion by taking a formal loan, even though access to this infrastructure is still relevant, its effect is decreasing. Therefore the national educational level and Credit Information Societies acquire relevance, as well as the employment vulnerability, which affects eligibility and the commitment that indebtedness entails. The significance of certain cultural traits in the credit static panel warns that, although financial inclusion can be promoted through standards vetted internationally, its effectiveness cannot be separated from the social context where they are implemented.
\end{abstract}

Key words: financial inclusion; asymmetric information; cultural traits; vulnerable employment

JEL classification: $G 2, G 18, G 21$, E2

\section{Introduction}

The study of the link between savings, credit and economic growth dates back, at least, to Bagehot (1873), Schumpeter (1934) and almost half a century later, to Hicks and Goldsmith (1969), McKinnon (1973) and Shaw (1973), who highlighted

\footnotetext{
* Received: 30-09-2019; accepted: 09-12-2019

1 Full Professor, Anáhuac University Mexico, Faculty of Business and Economics, Av. Lomas Anáhuac 46, Col. Lomas Anáhuac, Huixquilucan Estado de México, CP 52786. Scientific affiliation: sustainable economic growth, social capital \& financial inclusion. Phone: +5255 56270210 ext.8601.E-mail: lpavon@anahuac.mx. ORCID: 0000-0002-1410-034X.
} 
the importance of financial intermediation to transform savings into investment, although they attributed an exogenous character to it, partially due to the dominant paradigm of the time: Solow's growth models (1956). These models left little room for alternative engines to economic activity beyond technological progress, whose diminishing returns were forecasting a steady-state and absolute convergence between countries. The empirical evidence showed, however, divergent trajectories inconsistent with this initial hypothesis, which enables the hypothesis of conditional convergence, where the closeness between countries depends on whether or not they have similar parameters. This is how the literature of endogenous growth arises (Sala-i-Martin, 2006), where financial development acquires relevance (Levine, 1991; Greenwood and Smith, 1990), gradually discovering, as quantitative methods allow, its endogenous and asymmetric nature (Stiglitz and Weiss, 1981).

The Great Recession questions the benefits attributed to financial development in the economy, raising the possibility that this relationship could take the form of a Gompertz curve: greater financial development initially reduces liquidity constraints, promotes savings, investment, formality, and contributes significantly to growth, but once a certain threshold is exceeded, this link is diluted because its diminishing returns subtract resources to other sectors, and they could even be the reason why, as Minsky points out, over-indebtedness and financial crises can be the endogenous products of economic growth (Minsky, 1982). These diminishing returns to financial development question their traditional indicator of deepening (credit and/or deposits on GDP) and suggest, instead, indicators that evaluate the access and use of these services, or in other words, financial inclusion.

This vision is reinforced as global inequality, environmental deterioration and the ambivalent role of technological progress in employment extend and drive the literature of sustainable growth (Spence, 2011 and Rodrik, 2018). On it, environmental care and equity are no longer a simple desirable result of growth, but an indispensable input for its sustainability (Agenor et al., 2017). The Sustainable Development Goals, based on the Millennium Goals, are now universally applicable and pay more attention to the media, particularly around the mobilization of resources through financial inclusion (UN, 2016). This constitutes a policy of productive insertion, which expands the possibilities of family saving and consumption, while at the same time enhances the talents and investment opportunities of companies, which confirms its relevance beyond equity.

Financial inclusion implies the access, intensity and regular use, by all segments of society, of a wide range of financial services, affordable, timely and adequate, in a context of competition, transparency and financial education, to promote the welfare of its users and systemic stability, thus contributing to sustainable economic development that promotes economic and social inclusion (Pavón, 2016). By incorporating systemic elements in the definition, we ensure that financial stability and inclusion are compatible objectives, by highlighting the creation of instruments 
such as high-risk mortgages in the United States, which despite being created for purposes other than social inclusion, provided indiscriminate access to real estate credit to families that were previously excluded from the financial system, which helped to trigger the global financial crisis of 2008. In this context, financial inclusion does not mean financial services for all at any cost: attempts to subsidize or release them have proven to be self-defeating, as they can lead to microeconomic distortions such as excessive risk taking and over-indebtedness. Additionally, as it is feasible to have an oversized and non-inclusive financial system, a first estimation of a country's financial development from a higher social perspective requires knowing the percentage of the population that accesses these services (Pavón, 2019). In previous works (Pavón 2018 \& 2019), it was deeply examined the importance and meaning of financial inclusion, and the different international databases were explored to identify those available indicators that could be used as proxies of financial inclusion, as well as those which empirical literature suggested as explanatory. This exploratory analysis allowed to group the indicators by categories and to identify two different degrees of financial inclusion: savings account ownership and loan eligibility, both from formal financial institutions. Some potential determinants of financial inclusion were then preliminary tested through models based on panel data, by the credit and the savings fronts. Variables linked to access infrastructure as well as financial services characteristics seem to be relevant, but also barriers driven by non-financial aspects such as cultural traits, education or income of the potential customers.

To advance in the study of financial inclusion in its different stages, theoretical frameworks of savings, credit and sustainable growth are now been incorporated, to go forward to a more rigorous foundations from the empirical analysis of financial inclusion previously developed. This paper analyzes the determinants of access to savings and credit and builds two models that allow them to be validated statistically, which is essential to issue a diagnosis able to guide public policy, development banking, and supranational organizations, among others, to the fields of effective action to promote financial inclusion. The questions to be answered are the following: How are access and financial inclusion measured and why do they differ from financial penetration? What is its relevance in the framework of sustainable economic growth? What determines access to financial services and what is required to advance on financial inclusion? Are the factors of both decisions common or are there distinctive factors in each decision?

The hypotheses to be tested are:

$H_{o} a$ : given certain socioeconomic characteristics of the national population, their savings account ownership relies on the available infrastructure of financial services, but it is also a rational decision that weighs the cost-benefit of saving, where individual incentives, as well as information constraints that affect the attractiveness of financial products, are decisive. 
To get into the use of these products (hiring a credit or insurance), they must be affordable, accessible and adequate. Therefore, the second hypothesis test is:

$H_{o} b$ : given certain socioeconomic characteristics of the national population, accessing a credit depends on the available infrastructure of financial services, but it is also a rational decision that weighs the cost-benefit of this action, where the incentives for consumption and investment, information problems that affect not only the attractiveness of financial products but also the country cultural traits, are decisive.

The work is divided into six sections. Once the importance of financial inclusion in the framework of sustainable growth has been established in this first section, a second one presents an overview of the literature on savings and credit, which allows establishing the factors that influence the process of opening a savings account and contracting a loan. A third section includes the research methodology, mainly the methods applied to estimate the macro-econometric models included here, while in a fourth section the empirical data and the results obtained are detailed, with emphasis on the key indicators. The analysis and discussion of the results are carried out afterwards, and finally, the sixth and final section establishes recommendations and main limitations of the study, as well as possible future research directions.

\section{Literature review}

Prior to the Great Depression, saving was considered an engine of the economy, by providing funds for investment financing. However, after the crises of the thirties, Keynes (1936) and his frugality paradox reduced the enthusiasm about the benefits of saving, that could constitute, at least in the short term, a leakage of effective demand and growth. In the forties, empirical evidence claimed its growthpromoting role (Kuznets et al., 1946), and since then, the literature on savings and credit has had a great boom, so in the following lines there is only a brief summary of its evolution, which aims to be more descriptive than exhaustive, and whose purpose is to explore the subject under a new perspective of financial inclusion, as an alternative to the diminishing returns of financial deepening. It is based on microeconomic models since the magnitude of savings and credit finally results from supply and demand interaction of loanable funds, and then goes into macrofinancial studies since the fundamentals of this nature underlying to a country will be responsible for its evolution.

Friedman Permanent Income Hypothesis (1957) and Modigliani and Brumberg Life Cycle (1957) research constitute the fundamental theoretical microeconomics reference to understand savings and credit. Friedman showed that consumption depends not only on disposable income but also on permanent income and wealth, 
which gives them greater stability and has been empirically validated by authors such as Masson et al. (1995). In line with the Friedman model, Modigliani and Brumberg state that consumption, savings, and credit depend on the expected income for life, so that economic agents seek to soften consumption over time, saving in times of economic abundance and using them and even borrowing in times of scarcity. This hypothesis gives relevance to sociodemographic variables and their tendency since people close to the average should be the ones that save the most. Empirical evidence confirms this, since countries with a greater proportion of young people and the elderly within the population tend to save less (Luehrmann, 2003), and in parallel, the national social security network, pension funds, and the capital market development alters savings and credit patterns, as they affect this intertemporal allocation of resources (Samuelson \& Nordhaus, 2010). Furthermore, human capital (education, training and technological literacy) is increasingly being pointed out in the theoretical and empirical literature for its bidirectional effect on financial inclusion (Holzmann, 2010), while firm characteristics such as their size or age (Focarelli and Rossi, 1998) are used in empirical studies, but have little presence in the theoretical field, perhaps due to the difficulty of isolating them from other factors, such as the institutional framework or the degree of development.

National cultural traits are also relevant, even when their analysis in the financial field is incipient. These population attributes that determine attitudes and competencies which are part of social capital (Diamond, 1997), predispose attitudes towards savings and credit, including their confidence in the financial system, while delineating family cohesion or solidarity, which determines access to informal financing from family and friends, including remittances. Those include the longterm vision, individualism or uncertainty avoidance, often used as exogenous variables, valid in the short or medium-term since all these characteristics change at a relatively slow pace from generation to generation (Becker, 1976). Its importance lies in the premise that they explain why the same financial inclusion policies give rise to different results depending on the country where they are applied.

Both in the micro and macroeconomic field, higher current or expected income improves the financial situation of families and companies, since it allows them to save, support higher levels of indebtedness and, consequently, consume and invest more (Kashyap, Stein and Wilcox, 1993), driving growth. However, this relationship is not always consistent (Bernanke and Gertler, 1989), since in times of boom, companies could dispense with external sources of financing, such as bank credit, and households could reduce their debt levels (Ozcan et al., 2003). In recent years, in addition to the level of current and expected income as an explanation of savings and credit, its volatility and, linked closely to it, the quality and productivity of its sources, have been added. The use of financial products, particularly when they involve the payment of commissions, require documentation, guarantees, and a long-term commitment, which potential users are not always in a position 
to meet. The precariousness of employment and the proliferation of microbusinesses, translates into their contingent, informal nature, without social benefits or regulation, which creates in the economic agents a perception of vulnerability, which reduces their productivity (Hyman, 2016) and incapacitates them to generate savings or be subject to credit (ILO, 2019).

The increasing divergence in the level and trajectory of savings and credit between countries has more recently inspired numerous articles that are oriented to look for patterns and macro-financial elements besides the income that explain them and that have theoretical support, although their effects are not always clear (El-Seoud, 2014):

The first element is inertia since the private savings and credit of the current period are affected by those of the previous one (De la Torre, Feyen and Ize, 2013), which intuitively makes sense, considering that both are flow and stock, subject to a multiplicative factor that constitutes the interest rate. Likewise, the infrastructure for access to financial services induces a greater financial inclusion and this, in turn, promotes the creation of greater access channels, albeit at a decreasing rate (Claessens, 2006 and Roa et al., 2014).

The second essential factor in the study of savings and credit, from an aggregate perspective, are variables such as the real interest rate, the monetary policy or the financial system development (Cole, 2009). As a return, the interest rate has a positive effect on savings and credit supply, as it allows more income in the future, both to the lender and the depositor. However, it also affects the borrower negatively, economic activity and investment, and therefore income, particularly in debtor countries, so it would eventually have a negative impact on private savings and credit (McKinnon, 1973). This explains the lack of robustness of the effect of this variable as an explanation of savings and credit when modifying the time interval of study, so indicators that reflect more directly the imperfections and the financial market development and its effect on the relative cost of its products are currently preferred, such as the bank spread, the active-to-passive rate ratio or the depth of Credit Information Companies (CICs). This line of research relaxes the assumption of perfect financial markets so that the supplier's concentration, information problems, as well as the regulatory burden are indicated as responsible for credit rationing, documentation barriers and the high cost of these services (Beck et al., 2007). Interest rates, in turn, depend on the monetary policy and monetization of the economy, which are directly related to the evolution of prices (Hoffmann, 2001).

To close this section, it remains to mention the third category of variables, which in line with the Ricardian equivalence, should have a negative impact on private savings, given its complementary nature. This refers to public and external savings. On fiscal policy, as crowding-out effect predicts, a budget deficit would 
be accompanied by an increase in private savings to the detriment of credit, particularly if it comes from higher current spending (Masson et al., 1995). This effect is reinforced by considering the theory of sustainability of public debt (Boskin, Flemming \& Gorini, 1987), which poses that its increase would lead to greater country risk and a possible reduction in the credit rating, which would reduce the attractiveness of internal savings (Khan et al., 2001).

Regarding external savings and other related variables, such as the terms of trade or the entry into the country of foreign banks, their effect on savings and credit has also been analyzed in the literature (Eichengreen and Steiner, 2008; Tressel and Detragiache, 2008, among others), even though in practice their results are weak and the sense of causality questionable.

\section{Methodology}

Once the main determinants of savings and credit have been identified in the literature consulted, the next step is to validate them statistically. This required to explore and tie the different databases available, and then choose the variables that would function as dependent or explanatory, which required factorial style statistical analysis, to group the indicators into categories and, through correlation analysis, exclude those that seem to capture the same information. In the case of the dynamic panel used for savings, it was also necessary to define how the potential explanatory variables would be treated (endogenous, predetermined or exogenous) and under what constraints, calibrating their significance and the ones of the model. The unified database resulted in two balanced panels (savings and credit), where the Breusch-Pagan test found that the individual effects are relevant and while Hausman test validated the use of a panel of random effects instead of fixed effects. In both models, when running the static panels with random effects, the presence of heteroscedasticity and autocorrelation was detected through the modified Wald test and the Wooldridge test respectively. To solve these problems together, the Panel Corrected Standard Errors (PCSE) estimators were used:

$$
y_{i t}=x_{i t} \beta+\epsilon_{i t}
$$

Where $i=1 ; \ldots ; m$ is, in this case, the number of countries; $t=1 ; \ldots ; T i ; T i$ is the number of years for the country $i$; and $\in_{i t}$ a disturbance term, which may be correlated along $t$ or contemporaneously correlated across countries. PCSE allows to estimate the parameters by Ordinary Minimum Squares (without autocorrelation), or by Prais-Winsten, or Cochrane-Orcutt equation (with the firstorder autocorrelation), when disturbances cannot be considered as independent and identically distributed (iid), either because they are heteroscedastic or because they are correlated in a contemporary way between countries. All estimates from Prais- 
Winsten are conditional to those estimated with autocorrelation, or in other words, the estimator of the variance-covariance matrix of the parameters is asymptotically efficient under the assumed covariance structure of the disturbances and uses the Minimum Feasible Generalized Squares estimated out of the disturbance covariance matrix (Kmenta, 1997; Stata, 2019).

However, in the case of the savings model, the inability of static methods to explain it and to properly treat endogeneity (Dosi, 1988), requires the use of a dynamic panel $^{2}$, whose analysis has evolved considerably in recent years in two main lines:

1) The traditional method of instrumental variables, which uses a proxy variable as an instrument of the endogenous variable (Cameron \& Triverdi, 2009), however it does not allow analyzing the endogeneity of the model, since it does not include the dependent variable delayed as a regressor.

2) The use of lags as instruments of the endogenous variable.

The first generation models in this category, construct instrumental variables from endogenous variables lags that can be applied in differences:

$$
X_{(t-n)}-X_{(t-(n-1))}
$$

Or in levels:

$$
X_{(t-n)}
$$

Thus, the larger the period, the more instruments will be available. This group includes the Difference GMM (Generalized Method of Moments) estimators, developed by Arellano and Bond (1991), which use the difference lags as instruments.

The second-generation models allow estimating panels with a short time series with a small number of instruments, and includes variables lags as instruments, in levels:

$$
Y_{t}=Y_{t-1} ; Y_{t-(n-1)}=Y_{t-n}
$$

Or in differences:

$$
\Delta Y_{t-1}=Y_{t-2}-Y_{t-1}
$$

\footnotetext{
2 Static panels, irrespective of being models with fixed or random effects, assume in both cases these effects as a constant over time. The restriction above makes static models limited to be able to consider the dynamics of time variation, or the endogeneity (Labra \& Torrecillas, 2018).
} 
$Y_{t-n}$ being the instrument of $Y_{t-(n-1)}$. In this category, the Arellano and Bover estimator (1995) stands out, that by incorporating variables at levels it creates a system of equations (System GMM). The equations that allow its calculation are the following:

$$
\begin{aligned}
& Y_{i t}=\alpha_{i, t-1}+\beta X_{i} t+\varepsilon_{i t} \\
& \varepsilon_{i t}=\mu_{i}+\vartheta_{i t} \\
& E\left(\mu_{i}\right)=E\left(\vartheta_{i t}\right)=E\left(\mu_{i} \vartheta_{i t}\right)=0
\end{aligned}
$$

$Y_{i t}$ is the dependent variable of $i$ (country) in $t$ (year) and $X_{i t}$ is the independent variable of $i$ in $t$. The error term $\varepsilon_{i t}$ has two orthogonal components: $\mu_{i}$ that captures the fixed disturbances and $\vartheta_{i t}$ the idiosyncratic ones. The Arellano-Bover/BlundellBond estimator augments Arellano-Bond by making an additional assumption that first differences of instrument variables are uncorrelated with the fixed effects. This dramatically improve efficiency by allowing the introduction of more instruments. It builds a system of two equations - the original equation and the transformed one- and is known as system GMM.

A similar estimator is xtabond2 (Roodman, 2006), which follows the modelling line developed by Arellano and Bond (1991 \& 1995) and Blundell and Bond (1998), but also introduces more options in the use of instruments. The GMM Dynamic Panel Data-Two Step-Robust Standard (xtabond2) can use instruments in differences and in levels which allows to work separately the endogeneity of the dependent or independent variables, so the lags of the dependent variable as regressor can be excluded. Therefore, the versatility of this estimator allows building the savings model in this investigation, as it reduces the information losses and the probability of over-identification due to the proliferation of instruments (Labra \& Torrecillas 2018). 


\section{Empirical data and results}

\subsection{Empirical data}

The sources of information are the World Bank (WB, 2019), the International Labor Organization (ILO, 2019), the World Economic Forum (Schwab, 2018), the International Monetary Fund (IMF, FAS 2019), Hoefstede et al. (2010) and The Economist Intelligence Unit (2018). Introducing information from a variety of sources requires to remove several years and countries as well as to estimate some missing isolated data through a linear extrapolation (Armstrong and Collopy, 1993). The two models finally estimated are annual, for the 2006 - 2017 period, which correspond to commercial banks. The sample includes, in the case of the savings model, 26 countries $^{3}$ and in the case of the credit model, 55 countries ${ }^{4}$.

The first step is to define the representative variables of access to the financial system and the one of financial inclusion to be included as a dependent variable in the corresponding model. The indicators closest to the financial access available in the databases are the number of savings accounts and, in the case of financial inclusion, commercial bank borrowers, both for each number of inhabitants, as they are the only ones that capture, even partially, the financial inclusion that an indicator of financial depth cannot (monetary aggregates or credit to the non-financial private sector on GDP), since the funds are traditionally concentrated in a small number of companies and individuals. Likewise, the use of these variables is justified, not only by the importance of commercial banking in the provision of basic financial services, but also because these are a prerequisite for access to more sophisticated products (Sarma, 2008).

Both models would be expected to share some explanatory variables since the literature seems to support a complementary instead of a mutually exclusive relationship between savings and credit ${ }^{5}$. Economic agents usually save for years to

\footnotetext{
3 Albania, Argentina, Bangladesh, Belgium, Brazil, Chile, Colombia, Croatia, Dominican Republic, Arab Republic of Egypt, Estonia, Indonesia, Italy, Latvia, Lebanon, Malaysia, Namibia, Peru, Portugal, Romania, Serbia, Singapore, Tanzania, Thailand, Uruguay and Zambia.

4 Argentina, Azerbaijan, Bangladesh, Belize, Botswana, Brazil, Brunei Darussalam, Burundi, Cape Verde, Colombia, Democratic Republic of the Congo, Costa Rica, Croatia, Dominican Republic, Ecuador, Arab Republic Egypt, Estonia, Gabon, Georgia, Ghana, Italy, Kenya, Kuwait, Republic of Kyrgyz, Latvia, Lebanon, Lesotho, Madagascar, Malaysia, Moldova, Burma, Namibia, Nigeria, Pakistan, Paraguay, Peru, Qatar, Rwanda, Saudi Arabia, Seychelles, Sierra Leone, Singapore, Swaziland, Tajikistan, Tanzania, Thailand, Timor-Leste, Tunisia, Turkey, Uganda, Uruguay, Uzbekistan, Yemen, Zambia and Zimbabwe.

5 In this regard, it should be noted that even when the second model has almost half of the countries included in the first one, both samples share a similar average economic development level as well as continental representation, in addition to the fact that the savings model sample is included in more than $73 \%$ of the credit model sample, thus allowing these kind of comparisons.
} 
undertake a project, such as a business or a house, and only borrow as a supplement once they decide to carry it out. Also, credits for medical purposes are not frequent and depend on the strength of social security networks or, in their absence, usually come from informal credits provided by savings from family and friends. In $2017,27 \%$ of adults in advanced economies and $10 \%$ in developing ones reported having a home loan from a financial institution. On the other hand, $5 \%$ of adults in industrialized countries requested a loan for medical or health expenses and $11 \%$ in emerging countries, where these credits came mostly (79\%) from family members, friends or other informal sources. $17 \%$ percent of adults in the world reported having saved or requested a loan in the last 12 months for business and among them, 79\% had saved and then borrow as a complement (Demirgüç-Kunt et al., 2018).

In both models, a representative variable of infrastructure of access to financial services is included. The number of automated teller machines (ATMs) and bank branches by a certain number of inhabitants or kilometers is tested.

Once the access was incorporated into the model, the next step was to test the barriers and inducers to the use of financial products indicated in the literature by categories. These can be found inside or outside the financial field. Within the sector, variables related to the regulatory framework are identified; financial consumer protection; concentration of financial institutions; access barriers such as required documentation, guarantees or collateral; palliative to information problems such as credit bureaus or Credit Information Societies (CIS) and, linked to it, the cost of financial products. Outside the sector, those linked to the business and macroeconomic environment are identified; the labor market; rule of law and business ethics; cultural traits: education and training, as well as information and communication technologies.

Although as already mentioned, several years and countries were lost in the models finally estimated due to the use of different sources of information, along with the fact that it was necessary to transform several indicators in indexes to homogenize the scale of all the variables included in the model. A preliminary description of their original values is presented in table 1 . 
Table 1: Descriptive statistics for some financial inclusion indicators and its determinants

\begin{tabular}{|c|c|c|c|c|c|c|c|}
\hline \multicolumn{2}{|c|}{ Variable } & Mean & $\begin{array}{c}\text { Std. } \\
\text { Deviation }\end{array}$ & Minimum & Maximum & Obs. & Source \\
\hline $\begin{array}{l}\text { Deposit in } \\
\text { commercial } \\
\text { banks per } \\
\text { thousand } \\
\text { adults }\end{array}$ & $\begin{array}{r}\text { Overall } \\
\text { Between } \\
\text { Within }\end{array}$ & 619,337 & $\begin{array}{l}518,076 \\
494,521 \\
165,575\end{array}$ & $\begin{array}{c}1.530 \\
26.573 \\
27.4915\end{array}$ & \begin{tabular}{l|}
3166,130 \\
2251,228 \\
1534,239
\end{tabular} & $\begin{array}{c}\mathrm{N}=756 \\
\mathrm{n}=63 \\
\mathrm{~T}=12\end{array}$ & $\begin{array}{l}\text { International } \\
\text { Monetary } \\
\text { Fund, Financial } \\
\text { Access Survey } \\
\text { (IMF, FAS } \\
\text { 2019) }\end{array}$ \\
\hline $\begin{array}{l}\text { Borrowers } \\
\text { per } \\
\text { thousand } \\
\text { adults }\end{array}$ & $\begin{array}{r}\text { Overall } \\
\text { Between } \\
\text { Within }\end{array}$ & 174,572 & $\begin{array}{c}208,5725 \\
203,4973 \\
51,910\end{array}$ & $\begin{array}{c}0,1300 \\
1,6842 \\
-65,1432\end{array}$ & \begin{tabular}{c|}
1233,000 \\
1032,577 \\
433,857
\end{tabular} & $\begin{array}{c}\mathrm{N}=756 \\
\mathrm{n}=63 \\
\mathrm{~T}=12\end{array}$ & $\begin{array}{l}\text { (IMF, FAS } \\
\text { 2019) }\end{array}$ \\
\hline $\begin{array}{l}\text { ATMs/ } \\
10.000 \\
\text { inhabitants }\end{array}$ & $\begin{array}{r}\text { Overall } \\
\text { Between } \\
\text { Within }\end{array}$ & 30,029 & $\begin{array}{c}30,199 \\
28,807 \\
9,709\end{array}$ & $\begin{array}{c}0 \\
0 \\
-17,054\end{array}$ & $\begin{array}{c}140 \\
113,083 \\
99,029\end{array}$ & $\begin{array}{c}\mathrm{N}=756 \\
\mathrm{n}=63 \\
\mathrm{~T}=12\end{array}$ & $\begin{array}{l}\text { (IMF, FAS } \\
\text { 2019) }\end{array}$ \\
\hline $\begin{array}{l}\text { Vulnerable } \\
\text { employment } \\
\text { (\% of total } \\
\text { employment }\end{array}$ & $\begin{array}{r}\text { Overall } \\
\text { Between } \\
\text { Within }\end{array}$ & 42,220 & $\begin{array}{c}25,371 \\
25,444 \\
2,392\end{array}$ & $\begin{array}{c}0,160 \\
0,203 \\
26,889\end{array}$ & $\begin{array}{l}93,210 \\
92,503 \\
60,986\end{array}$ & $\begin{array}{c}\mathrm{N}=756 \\
\mathrm{n}=63 \\
\mathrm{~T}=12\end{array}$ & $\begin{array}{l}\text { ILO, } \\
\text { International } \\
\text { Labor } \\
\text { Organization, } \\
2019\end{array}$ \\
\hline $\begin{array}{l}\text { Quality of } \\
\text { education } \\
\text { (1=low to } \\
7=\text { high) }\end{array}$ & $\begin{array}{r}\text { Overall } \\
\text { Between } \\
\text { Within }\end{array}$ & 3,625 & $\begin{array}{l}0,844 \\
0,815 \\
0,249\end{array}$ & $\begin{array}{l}1,810 \\
1,987 \\
2,543\end{array}$ & $\begin{array}{l}6,160 \\
6,085 \\
4,496\end{array}$ & $\begin{array}{c}\mathrm{N}=653 \\
\mathrm{n}=55 \\
\mathrm{~T}=12\end{array}$ & $\begin{array}{l}\text { World } \\
\text { Economic } \\
\text { Forum (WEF, } \\
\text { 2018) }\end{array}$ \\
\hline $\begin{array}{l}\text { Depth of } \\
\text { Credit Info. } \\
\text { Co. CICs } \\
\text { ( } 0=\text { low to } \\
8=\text { high })\end{array}$ & $\begin{array}{r}\text { Overall } \\
\text { Between } \\
\text { Within }\end{array}$ & 4,517 & $\begin{array}{l}3,110 \\
2,897 \\
1,185\end{array}$ & $\begin{array}{c}0 \\
0 \\
-1,816\end{array}$ & $\begin{array}{c}8 \\
8 \\
10,517\end{array}$ & $\begin{array}{c}\mathrm{N}=756 \\
\mathrm{n}=63 \\
\mathrm{~T}=12\end{array}$ & $\begin{array}{l}\text { World Bank } \\
(\mathrm{WB}, 2019)\end{array}$ \\
\hline $\begin{array}{l}\text { Pragmatism } \\
(0=\text { low to } \\
100=\text { high })\end{array}$ & $\begin{array}{r}\text { Overall } \\
\text { Between } \\
\text { Within }\end{array}$ & 35,488 & $\begin{array}{c}21,263 \\
21,655 \\
0\end{array}$ & $\begin{array}{c}4 \\
4 \\
35,488 \\
\end{array}$ & $\begin{array}{c}82 \\
82 \\
35,488 \\
\end{array}$ & $\begin{array}{c}\mathrm{N}=359 \\
\mathrm{n}=30 \\
\mathrm{~T}=12\end{array}$ & $\begin{array}{l}\text { Hoefstede et al. } \\
(2010)\end{array}$ \\
\hline $\begin{array}{l}\text { Uncertainty } \\
\text { avoidance } \\
(0=\text { low to } \\
100=\text { high })\end{array}$ & $\begin{array}{r}\text { Overall } \\
\text { Between } \\
\text { Within }\end{array}$ & 64,223 & $\begin{array}{c}19,029 \\
19,534 \\
0\end{array}$ & $\begin{array}{c}8 \\
8 \\
64, .223\end{array}$ & $\begin{array}{c}99 \\
99 \\
64,223\end{array}$ & $\begin{array}{c}\mathrm{N}=329 \\
\mathrm{n}=30 \\
\mathrm{~T}=12\end{array}$ & $\begin{array}{l}\text { Hoefstede et al. } \\
(2010)\end{array}$ \\
\hline
\end{tabular}

Source: Author's elaboration based on the revision of the sources cited on the table and processed in Stata. 


\subsection{Panel data analysis results}

This section presents the results of the estimated models.

Table 2: Dynamic panel results: Savings

Dependent variable: deposit in commercial banks per thousand adults' index

\begin{tabular}{|c|c|c|c|c|}
\hline Variable & Coefficient & & & SE \\
\hline \multicolumn{5}{|l|}{ Predetermined variables } \\
\hline $\begin{array}{l}\text { - Vulnerable employment (\% of total } \\
\text { employment) }\end{array}$ & $-0,32861 * * *$ & & & 0,10072 \\
\hline - Quality of education & $3,27774 * * *$ & & & 0,96396 \\
\hline \multicolumn{5}{|l|}{ Endogenous variables } \\
\hline $\begin{array}{l}\text { - Depth of Credit Information Companies } \\
\text { (CICs) }\end{array}$ & $1,98857 * * *$ & & & 0,74228 \\
\hline - ATMs/ 10.000 inhabitants index & $0,46758 * * *$ & & & 0,13587 \\
\hline Constant & 9,29162 & & & 8,14251 \\
\hline Wald Chi Square Test & $\mathrm{Chi}^{2} 68,91$ & Prob $>\mathrm{Chi}^{2}$ & & 0,000 \\
\hline Hansen Test & $\mathrm{Chi}^{2}$ Test 30,75 & Prob $>\mathrm{Chi}^{2}$ & & 0,377 \\
\hline Arellano-Bond Test & $\operatorname{Ar}(1)$ & $z=-0,75$ & Prob $>z$ & 0,000 \\
\hline (first differences) & $\operatorname{Ar}(2)$ & $z=-0,09$ & Prob $>z$ & 0,377 \\
\hline Observations / Groups & & $598 / 55$ & & \\
\hline Instruments & & 34 & & \\
\hline
\end{tabular}

Note: $* * *$ and $* * *$ indicate significance at $10 \%, 5 \%$ and 1\%. GMM Dynamic Panel Data-Two Step-Robust Standard.

Source: author 's process in Stata.

In the savings model (Table 2), various options are calibrated, until the best alternative is found: a dynamic panel xtabond2, where the estimation is made only in differences, using the first lag and without incorporating the lagged dependent variable as explanatory, to avoid over-identification of the model. With the same purpose, an instrument is created only for each variable and lag, instead of one for each period of time, variable and lag. The robust and two-stage analysis is carried out, which uses the heteroscedastic weights matrix, as indicated in this case, as it is more efficient while avoiding bias in the estimate derived from the absence of homoscedasticity.

According to the criteria of Roodman (2006) for xtabond2, the balanced panel includes a few countries (55) in relation to the years (12), but its structure coincides with that of other recognized macroeconomic studies, which face the same restrictions of information (Labra and Torrecillas, 2018) for what is valid, as long as there is no proliferation of instruments. 
Even though the model does not show signs of over-identification since the number of instruments (34) is considerably lower than the number of groups (55), the Hansen Test suggested by Roodman (2006) is used to rule out this problem. In addition, it is verified by the Arellano-Bond test that the errors are not serially correlated so that the estimate is consistent and justifies dynamic models that use lags in differences or levels as instruments. The explanatory power of the model is evaluated by the Wald test that shows that the variables together explain the dependent variable. Likewise, the significance of each of the explanatory variables shows that these have been well selected and adequately expressed.

Table 3: PCSE static panel results: Credit

Dependent variable: borrowers per thousand adults' index

\begin{tabular}{|c|c|c|}
\hline Variable & Coefficient & SE (hetero) \\
\hline Depth of Credit Information Companies(CICs) & $0,09945 * * *$ & 0,02985 \\
\hline ATMs/ ten thousand inhabitants index & $0,29924 * *$ & 0,12595 \\
\hline ATMs/ ten thousand inhabitants index ${ }^{2}$ & $-0,00264 * *$ & 0,00111 \\
\hline Uncertainty avoidance & $-0,10465 *$ & 0,06071 \\
\hline Pragmatism & $-0,32233 * * *$ & 0,07674 \\
\hline Quality of education & $3,74031 * *$ & 1,20457 \\
\hline Vulnerable employment ( $\%$ of total employment) & $-0,17584 * * *$ & 0,03660 \\
\hline $\mathrm{R}^{2}$ & & 0,7106 \\
\hline \multicolumn{3}{|l|}{ Wald Test } \\
\hline $\mathrm{Chi}^{2}$ & \multicolumn{2}{|c|}{373,99} \\
\hline Prob $>\mathrm{Chi}^{2}$ & \multicolumn{2}{|c|}{0,0000} \\
\hline \multicolumn{3}{|l|}{ Hausman Test } \\
\hline $\mathrm{Chi}^{2}$ & \multicolumn{2}{|c|}{4,95} \\
\hline Prob $>\mathrm{Chi}^{2}$ & \multicolumn{2}{|c|}{0,2926} \\
\hline Rho & \multicolumn{2}{|c|}{0,90356} \\
\hline \multicolumn{3}{|c|}{ Breusch-Pagan Lagrange Multiplier Test (random effects) } \\
\hline Chibar $^{2}(01)$ & \multicolumn{2}{|c|}{526,87} \\
\hline Prob $>$ Chibar $^{2}$ & \multicolumn{2}{|c|}{0,0000} \\
\hline Observations & \multicolumn{2}{|c|}{224} \\
\hline Countries (panels) & \multicolumn{2}{|c|}{22} \\
\hline
\end{tabular}

Note: $* * *$ and $* * *$ indicate significance at $10 \%, 5 \%$ and $1 \%$. Regression xtpcse het $\mathrm{c}(\operatorname{ar} 1)$.

Source: author 's process in Stata.

For the credit model (Table 3), a static panel and the PCSE methodology are used, whose parameters are estimated by a Prais-Winsten equation, since the firstorder autocorrelation has been detected, in addition to heteroscedasticity. Initially, dichotomous time variables were included in order to capture the existence of 
potential common time effects applicable to all countries. However, these effects were not significant according to Wald parameter test (testparm18 in Stata), therefore it was concluded that they did not belong to the model and they were removed. The estimate passes the test of the non-existence of omitted and redundant variables, as well as non-over-identification. It is also verified that the educational quality variable is correlated to a lesser extent with the vulnerable employment variable than with the dependent variable, to rule out any multicollinearity that the temporary component of the database could not correct (Gujarati, 2003).

Finally, as in the model of savings, the explanatory power of the model is evaluated. The Wald test indicates that the estimate is correct and that the variables together explain the dependent variable. Likewise, the high significance of each of the independent variables shows that the model can be validated.

\section{Results and discussion}

The dependent variables chosen for the savings and credit models were, respectively, depositors and borrowers for every ten thousand adults published by the World Bank (WB, 2019).

In both models, the variable selected to reflect the infrastructure for access to financial services was the number of ATMs for every one hundred thousand adults, since even when bank accounts are activated in branches, the use of these services depends on more and more of the geographical availability and temporal efficiency of the channels, which is easier and cheaper to achieve through ATMs or electronic banking.

Once the access is incorporated into the model, barriers and inducers to the use of financial products by categories are explored, within and outside the financial sphere. Both models share common explanatory variables such as palliative problems of asymmetric information characteristic of the sector, the quality and relevance of national education, as well as job insecurity, indicators repeatedly stated in the literature as determinants of financial inclusion. However, in accordance with economic theory, between the financial access that represents savings and the financial inclusion that constitutes access to credit, there are elements that differentiate them.

\subsection{Savings}

According to The World Bank, $69 \%$ of adults on the planet have a deposit account (2017), above $62 \%$ in 2014 and $51 \%$ in 2011, but with disparities: while in industrialized countries this indicator reaches 94\%, in developing economies it falls to $63 \%$. Regarding its temporal evolution, there are also significant differences 
between countries. Between 2014 and 2017, 515 million adults opened accounts, and 1.2 billion have done the same since 2011, but while in OECD economies the number of headlines increases considerably, in countries like Pakistan it hardly does (Demirgüc-Kunt et al., 2018).

The savings model captures these differences by using a coverage indicator as a dependent variable: the number of deposit account holders in commercial banks with residency in the country per thousand adults, which includes checking, savings, and term deposit accounts. It is incorporated as an index with a value from zero to one hundred to homogenize the scale of the different variables included in the model.

The infrastructure of access is captured, as already mentioned, through the number of ATMs per one hundred thousand inhabitants that is also included as an index whose value ranges from 0 to 100 . It is worth highlighting the endogenous nature of this indicator (using its first lag) with the explanatory variable, to the extent that a greater infrastructure of financial services, such as ATMs, induces greater coverage, which in turn leads to a greater presence of financial providers with their respective ATMs, as the number of customers grows. The model confirms its positive and significant effect on saving, as well as its endogenous character.

The variables chosen for their high explanatory power, both individually and together, in addition to the mentioned access indicator, are described below.

Regarding the variables of the financial sector, their concentration and information problems seem to be captured in the depth index of the Credit Information Companies (CICs), whose relationship with the dependent variable is significant, positive and endogenous using its first lag, since as information problems are reduced, greater financial inclusion is observed, by reducing the cost of financial products and alleviating the risk of insolvency or illiquidity, both for the user and for the provider. Such inclusion, in turn, feeds CICs, which further reduces information asymmetries (Greenwald et al., 1984). This result is consistent with the one indicated in the literature (Hoffman, 2001) and in empirical studies (Pérez and Titelman, 2018).

A large number of variables of a non-financial nature were also tested and finally, two of them were chosen and treated, as being an exogenous requirement of the model to promote financial inclusion, as predetermined in its first lag: the quality index and relevance of education and vulnerable employment as a percentage of total employment.

The high significance of the education variable confirms the importance of human capital (Mulligan and Sala-i-Martin, 2000 and Sarma, 2008) as a prerequisite for bringing economic agents closer to the use of these and other services that promote sustainable growth. 
The precariousness of employment, incorporated as a barrier of access to savings of a predetermined nature, is more relevant for financial inclusion than income or employment itself. The indicator chosen to reflect job insecurity is that of vulnerable employment as a percentage of total employment published by the International Labor Organization (ILO, 2019) which represents self-employed workers or unpaid employed family members. A high proportion of vulnerable employment indicates a primary and/or informal economy, sometimes motivated by a generation of shorter quality jobs. These groups are more likely to fall into poverty, as they suffer from formal labor arrangements, social protection or safety nets to protect themselves from eventualities, which makes them unable to generate savings or be credit eligible. These results coincide with those obtained by Demirgüc-Kunt et al., (2018) and with the predictions of the theoretical literature (Hyman, 2016).

Finally, the constant term does not alter the coefficients, neither the significance of the variables or the explanatory power of the model, so it is decided to drop it, despite not being significant.

\subsection{Credit}

Credit coverage in the world is low, as economic agents, particularly in emerging countries, tend to finance their activities with their own or informal funds, either because they lack access to the formal system or because, even though they do have it they prefer not to use it. In 2017, $47 \%$ of adults worldwide reported having requested a formal or informal loan in the last 12 months, $64 \%$ in highincome countries and $44 \%$ in emerging countries. The use of informal sources of financing to alleviate short-term liquidity restrictions is partly explained by lower educational levels and partially because access to formal credit is more difficult for some population segments (youth, women, inactive and rural) and of the productive scope (small and young companies). For example, 35\% of small and $25 \%$ of large companies state that access to financing is a major obstacle to growth in emerging economies, whereas this last value falls to $8 \%$ in advanced economies. This explains why the sources of new loans vary widely between regions: while a financial institution was the main source in advanced OECD economies $(90 \%$ of the total) in 2017, in emerging countries almost half of the financing came from family and friend relatives (Demirgüc-Kunt et al., 2018).

Regarding its temporary trend, the proportion of adults with loans from a financial institution remains stable in the world: $23 \%$ of adults reported having a formal credit, including credit cards, between 2014 and 2017. However, this figure hides regional disparities since after the Great Recession, even though almost all over the world formal credit coverage increased, it did not do so in South Asia, where the percentage of loans from family or friends grew (Demirgüc-Kunt et al., 2018). 
In the credit model, the number of customers that obtained loans from financial institutions for every ten thousand adults is used as a financial inclusion representative variable to capture coverage and not just depth. It is incorporated as an index from zero to a hundred to homogenize the scale of the variables included in the model.

When analyzing the effect of access infrastructure on credit coverage among the population, it is found that, according to the literature (Roa et al., 2014), when the ATMs index increases so does financial inclusion, but each additional ATM has a smaller effect than the previous one, which is reflected by the negative sign of the fore mentioned square indicator. This happens because the large commercial chains, main ATMs expansion networks, are concentrated in urban areas, where there was already an access channel, so their contribution to financial inclusion declines as they multiply.

In addition to the financial services infrastructure indicator, the variables chosen for their high explanatory power, both individually and collectively, are described below.

In regards to barriers attributable to the financial sector, the variable that proved to be highly significant to induce credit was, as already mentioned, the one that represents palliative to asymmetric information: the depth of the CICs, in accordance with that indicated in the literature (Beck et al., 2007) and in the empirical works of Pérez and Titelman (2018).

The credit model also includes non-financial barriers and, as in the case of saving, education and labor vulnerability variables are significant. In regards to education, and in line with the theoretical framework of human capital models (Mulligan and Sala-i-Martin, 2000), the relevance of its quality is confirmed, but also of its relevance to face the challenges of a competitive economy (Schwab, 2018). And once again, the quality of employment is more relevant to financial inclusion than employment itself.

Finally, the initiatives to achieve greater financial inclusion cannot be separated from the social context where they are implemented. In particular, the national cultural traits influence the citizens' attitudes towards uncertainty and the time horizon of their planning. The model shows that in countries that are more risktolerant and have a long-term vision, hiring a bank loan is more feasible, as expected. Societies with low tolerance to uncertainty are more emotional and anxious, so they tolerate badly the risk posed by the prospect of borrowing over a period of time where there will be several events beyond their control. On the other hand, long-term orientation or pragmatism makes it possible to assess, regardless of their attitude towards risk, long-term commitments, since they show a futureoriented pragmatic perspective (Hofstede et al, 2010). 


\section{Conclusions}

This work raises the importance of financial inclusion and quantitatively assesses its possible engines, extracted from the literature review on these issues, by analyzing its two main indicators, holding a savings account and having a loan.

Through a dynamic panel, it is verified that the opening of a savings account requires, on the supply side, an infrastructure of access represented by ATM's coverage, as well as palliative to asymmetric information problems (CICs), while on the demand side, the quality and relevance of national education, as well as the stability and the formality of the sources of income of economic agents, are crucial. It is also found that as more economic agents enter the financial system, the access channels multiply and the information asymmetries are diluted, so that their effects on the coverage of these services are endogenous. To move towards a financial inclusion through borrowing, although the drivers remain the same as those for savings, this study shows that the infrastructure of access has a decreasing effect, so that given a certain quality and relevance of national education, the depth of the CICs acquires relevance, as well as the quality of the sources of income that allows the economic agent to be eligible and assumes the commitment that indebtedness entails. Likewise, the significance of certain cultural traits in the credit model, warns that although the financial inclusion can be promoted through internationally accepted standards whose effects are predictable, their degree of progress cannot be separated from the social context where these measures are implemented. The model shows that in countries with less uncertainty avoidance and with a long-term vision, hiring a bank loan is more feasible.

This analysis shows that in any financial inclusion strategy, a coordination effort between the different actors is required beyond the financial field and a longterm country project, which guides the actions of the government, banks and supranational agencies, among others, to the most effective fields of action to promote this pillar of sustainable development, particularly in emerging countries. Financial inclusion has grown and this behavior is likely to be maintained in the coming years, due to a large market that has not been served and its diversifying potential, but it is necessary to address the obstacles that keep a high proportion of vulnerable individuals and companies in the world to the liquidity restrictions that impose being financially excluded.

On the supply side, this study suggests that policies that promote the supply of low-cost accounts for basic services, or that seek to simplify and standardize the documentation necessary for account ownership through electronic platforms, are effective tools to expand coverage and alleviate information problems that limit credit. Likewise, technologies such as mobile banking or the use of identification based on biometric information constitute another promising channel to expand the use of these services in a secure way. Its impact can be reinforced by the adoption, by 
the private sector, of business models that complement the technological platforms, with the support of financial education and technological literacy programs.

On the demand side, it must be explored through a cost-benefit analysis, what it means moving from informality to formality in a country, its business culture and whether the characteristics of financial products as costs, conditions, guarantees or other barriers, correspond to the needs, culture, education, and stability of the sources of income of its potential users. In this order of ideas, and even when this work should be valued for its originality, as it constitutes a practically unprecedented effort to quantitatively evaluate financial inclusion and its possible determinants in the global sphere with a multidimensional and dynamic approach, weaknesses imputed to the panel models referring to assuming that economies share the same function and that this is relatively stable over time should not be overlooked. However, this paper contributes to the standardization of the study of this topic, as relevant as little explored. Its main contribution is that it forces the establishment of priorities of analysis, when considering the sources of information and their limits, in a schematic way and through an international comparison.

The narrow definition of human capital (education) and social capital (culture) that underlies this work constitutes another limitation that should not be underestimated. This definition also restricts the study to the national field, without considering the differences existing within the same country. However, the analysis period of just over a decade validates the unidirectional character established between culture, education, employment quality, and financial inclusion, since the persistence of national education and cultural traits, guarantees that any temporary effect that could lead to double causalities is marginal. Additionally, this work only seeks to explore whether or not there is a significant effect on the financial inclusion of these general characteristics, and not an exact quantitative relationship for statistical inference purposes.

One of the most promising lines of research derived from this document would be to identify, with greater precision, the channels that encourage or inhibit financial inclusion, through an analysis by the level of national development, or by distinguishing individuals or companies, people by gender and age and firms by size and economic activity. Although much of this information is already available, it will be necessary to wait a few years to have time-series-cross-sectional data that enables its statistical treatment.

\section{References}

Agenor, P., Izquierdo, A., Henning Tarp J. (2007) Adjustment Policies, Poverty, and Unemployment, The IMMPA Framework, Wiley-Blackwell Publishing, USA.

Arellano, M., Bond, S. (1991) "Some Tests of Specification for Panel Data: Monte Carlo Evidence and an Application to Employment Equations", The 
Review of Economic Studies, Vol. 58, No. 2, pp. 277-297, https://doi.org/ $10.2307 / 2297968$.

Arellano, M., Bover, O. (1995) "Another Look at the Instrumental Variable Estimation of Error-Components Models", Journal of Econometrics, Vol. 68, No. 1, pp. 29-51, https://doi.org/10.1016/0304-4076(94)01642-D.

Armstrong, S., Collopy, F. (1993) "Causal forces: Structuring Knowledge for Timeseries Extrapolation", Journal of Forecasting 12, pp. 103-115.

Bagehot, W. (1873) Lombard Street: A Description of the Money Market (1 Ed.). New York: Scribner, Armstrong \& Co.

Beck, T., Demirgüç-Kunt, A., Levine, R. (2007) "Finance, Inequality and the Poor", Journal of Economic Growth, Vol. 12, No. 1, Springer, pp. 27-49, https://doi. org/10.1007/s10887-007-9010-6.

Becker, G. (1976). The Economic Approach to Human Behavior. Chicago, USA: University of Chicago Press, pp. 3-14.

Bernanke, B. S., Gertler, M. (1989) "Agency Costs, Collateral, and Business Fluctuations", American Economic Review, vol. 79, No. 1, pp. 14-31, https:// doi.org/10.3386/w2015.

Blundell and Bond (1998), "Initial Conditions and Moment Restrictions in Dynamic Panel Data Models", Journal of Econometrics, vol. 87, issue 1, 115-143, https://doi.org/10.1016/S0304-4076(98)00009-8.

Boskin, M., Flemming J., Gorini, S. (1987) Private Saving and Public Debt, Blackwell, Oxford, UK.

Cameron, A.C., Triverdi, P.K. (2009). Microeconometrics using Stata. Stata Press, College Station, TX.

Claessens, S. (2006) "Corporate Governance and Development", World Bank Research Observer, Vol. 21, No. 1, pp. 91-122, https://doi.org/10.2139/ssrn.642721.

Cull, R. (2009) "Financial Development, Bank Ownership, and Growth: or, Does Quantity Imply Quality?" The Review of Economics and Statistics Vol. 91, No. 1, MIT Press, pp. 33-51, https://doi.org/10.1162/rest.91.1.33.

De la Torre, A., Feyen, E., Ize, A. (2013) "Financial Development: Structure and Dynamics". World Bank Economic Review, Vol. 27, No. 3, pp. 514-541, https:// doi.org/10.1093/wber/lht 005 .

Demirgüç-Kunt, et al. (2018) The Global Findex Database 2017: Measuring Financial Inclusion and the Fintech Revolution. World Bank Group, Washington, D.C.

Diamond, J. (1997) Guns, Germs, and Steel: The Fates of Human Societies. W.W. Norton.

Dosi, G. (1988) "Sources, Procedures, and Microeconomic Effects of Innovation", Journal of Economic Literature, Vol. 26, No. 3, American Economic Association, pp. 1120-1171. 
Eichengreen, B., Steiner, K. (2008) Is Poland at Risk of a Boom-\&-Bust Cycle in the Run-Up to Euro Adoption? NBER Working Paper, No. 14438, National Bureau of Economic Research, Inc., https://doi.org/10.3386/w14438.

El-Seoud, M. (2014) Household Saving Does it Matter to Bahrain? Lap Lambert Academic Publishing, USA.

Focarelli, D., Rossi, P. (1998) La domanda di finanziamenti in Italia e nelle diverse aree del Paese (1984-1996), temi di discussione del Servizio Studi di Banca d'Italia No. 333, Roma Italia.

Friedman, M. (1957) A Theory of the Consumption Function, Princeton University Press.

Goldsmith, R.W. (1969) Financial Structure and Development, New Haven, Yale University Press.

Greenwald, B., Stiglitz, J., Weiss, A. (1984) "Informational Imperfections in the Capital Market and Macro-Economic Fluctuations", American Economic Review Vol. 74, No. 2, pp. 194-199, https://doi.org/10.3386/w1335.

Greenwood, J., Jovanovic, B. (1990) "Financial Development, Growth, and the Distribution of Income", Journal of Political Economy, Vol. 98, No. 5, pp. 1076-1107, https://doi.org/10.1086/2617 20.

Gujarati, D. (2003) Basic Econometrics, fourth edition, Mc Graw Hill, United States Military Academy, West Point, USA.

Hicks, J. (1969) A Theory of Economic History, Oxford, Clarendon Press.

Hofstede, G., Hofstede, G.J., and Minkov, M. (2010) Cultures and Organizations, Software of the Mind. McGraw-Hill, New York, USA.

Hoffmann, S. (2001) Politics and Banking. Ideas, Public Policy, and the Creation of Financial Institutions. Johns Hopkins University Press.

Holzmann, R, (2010) "Bringing Financial Literacy and Education to Low and Middle-Income Countries", Pension Research Council WP, Vol. 38, https://dx. doi.org/10.2139/ssrn.17076 73 .

Hyman, L. (2016) "Temps, Consultants, and the Rise of the Precarious Economy", The Hedgehog Review, Vol. 18, No. 1, pp. 17-32.

ILO, International Organization of Labor (2019) Labor statistics, available at http:// www.ilo.org/global/lang--en/index.htm (accessed 15 June 2019).

IMF, International Monetary Fund (2019) Financial Access Survey (FAS), available at http://data.imf.org/FAS (accessed 2 March 2019).

Kashyap, A., Stein, J., Wilcox, D. (1993) "Monetary Policy and Credit Conditions: Evidence from the Composition of External Finance", American Economic Review, Vol. 83, No. 1, pp. 78-98, https://doi.org/10.3386/w4015.

Keynes, J. M. (1936) The General Theory of Employment, Interest, and Money. NY: Harcourt and Brace. 
Khan, A. (2001) "Financial Development and Economic Growth", Macroeconomic Dynamics, Vol. 5, No. 3, pp. 413-433.

Kmenta, J. (1997) Elements of Econometrics. 2nd ed. Ann Arbor: University of Michigan Press, p.127.

Kuznets, S., Epstein, L., Zenks, E. (1946) National Product since 1869. National Bureau of Economic Research, NBER Books, New York, USA.

Labra, R., Torrecillas, C. (2018) "Estimating Dynamic Panel Data. A Practical Approach to Perform Long panels", Revista Colombiana de Estadística, Vol. 41, No. 1, pp. 31-52, 2018, https://doi.org/10.15446/rce.v41n1.61885.

Levine, R. (1991) "Stock Markets, Growth, and Tax Policy, Journal of Finance, Vo. 46, No. 4, pp. 1445-1465, https://doi.org/10.1111/j.1540-6261.1991.tb04625.x.

Luehrmann, M. (2003) "Demographic Change, Foresight and International Capital Flow", MEA Working Paper, Vol. 30, No. 3, Mannheim University, Germany.

Masson, P., Bayoumi, T., Samiei, H (1995) "International Evidence on the Determinants of Private Saving", IMF Working Papers, Vol. 51, https://dx.doi.org/10.5089/ 9781451847055.001.

McKinnon, R. (1973) Money and Capital in Economic Development, The Brookings Institutions, Washington, D.C.

Minsky, H (1982). Inflation, Recession and Economic Policy, Brighton, Wheatsheaf.

Modigliani, F., Brumberg, R. (1954) Utility Analysis and the Aggregate Consumption Function: An Interpretation of Cross Country Data, in KK Kuridara (Ed.). Post- Keynesian Economics, Rutgers University Press, New Brunswick, pp. 128-197.

Mulligan, C., Sala-i-Martin, X. (2000) Measuring aggregate human capital, Journal of Economic Growth, Vol. 5, No. 3, pp. 215-252, https://doi.org/10.1023/ A:1009893417085.

Ozcan, K, Gunay, A, Ertac, S. (2003) "Determinants of Private Savings Behavior in Turkey", Applied Economics, Vol. 35, pp. 1405-1416, https://doi.org/10.1080/ 0003684032000100373.

Pavón, L. (2019) "Bank Account Ownership as a First Step to Financial Inclusion: Some of its Potential Determinants at a Global Level". Atlantic Review of Economics, Vol 2, $\mathrm{N}^{\circ} 3$ (under process of publishing).

Pavón, L. (2018)"International financial inclusion: some multidimensional determinants". Small Business International Review, SBIR, Volume 2, Number 2 (July-December), Murcia, Spain, pp. 1-14, https://doi.org/10.26784/sbir. $\mathrm{v} 2 \mathrm{i} 2.125$.

Pérez, E., Titelman, D. (2018) La inclusión financiera para la inserción productiva y el papel de la banca de desarrollo. ECLAC books, $\mathrm{n}^{\circ} 153$ (LC/PUB. 2018/18P), Economic Commission for Latin America and the Caribbean, Santiago de Chile. 
Roa, M. J., Alonso, G., Garcia, N., Rodríguez, D. (2014) Financial Education and Inclusion in Latin America and the Caribbean. Central Banks Programs and the Financial Superintendence. Center for Latin American Monetary Studies, Mexico City.

Rodrik, D. (2018) "Populism and the economics of globalization", Journal of International Business Policy, Vol 1, No. 1-2, pp. 12-33, https://oi.org/ 10.1057/s42214-018-0001-4.

Roodman, D., (2006) "How to Do Xtabond2: An Introduction to Difference and System GMM in Stata". Stata Journal, StataCorp LP, vol. 9, No. 1, pp. 86-136, https://doi.org/10.1177/1536867 X0900900106.

Sala-i-Martin, X. (2006) "The World Distribution of Income: Falling Poverty and ... Convergence, Period", The Quarterly Journal of Economics, Vol. 121, No. 2, pp. 351-397, https://doi.org/10.1162/qjec.2006.121.2.351.

Samuelson, P. and Nordhaus, W. (2010) Economía, con Aplicaciones para Latinoamérica, $19^{\mathrm{a}}$ edición. Pavón, L., Blanco, C. Rev, Mc Graw Hill, Mexico City.

Sarma, M. (2008) "Index of Financial Inclusion”, ICRIER Working Paper, No. 215, Indian Council for Research on International Economic Relations (ICRIER), New Delhi, India, pp. 1-27.

Schumpeter J. (1934) Theory of Economic Development: An Inquiry into Profits, Capital, Credit, Interest, and the Business Cycle. Harvard University Press, Cambridge, MA.

Schwab, K (2018) The Global Competitiveness Report 2018, World Economic Forum, Geneva, Switzerland.

Shaw, E.S. (1973) Financial Deepening in Economic Development, Oxford University Press.

Solow, R. (1956) "A Contribution to the Theory of Economic Growth". The Quarterly Journal of Economics, Vol. 70, No. 1, pp. 65-94, https://doi.org/10.2307/ 1884513.

Spence, M. (2011) The Next Convergence: The Future of Economic Growth in a Multispeed World, Farrar, Straus and Giroux Ed., New York, USA.

Stata (2019) Stata 16 Manuals: Longitudinal Data/ Panel Data Reference Manual. Stata Press, College Station, Texas, pp. 313-372.

Stiglitz, J., Weiss, A. (1981) "Credit rationing in markets with imperfect information", American Economic Review, Vol. 71, No. 3, pp. 393-410.

The Economist Intelligence Unit (2018) Global Microscope. The Enabling Environment for Financial Inclusion. Center for Financial Inclusion at Action, EIU, New York, NY.

Tressel, T., Detragiache, E. (2008) "Do Financial Sector Reforms Lead to Financial Development?: Evidence from a New Dataset", IMF Working Papers, Vol. 8, No. 265, pp. 1-42, https://dx.doi.org/10.5089/9781451871234.001. 
UN, United Nations (2016) Transforming Our World: the 2030 Agenda for Sustainable Development. A/RES/70/1. Sustainable Development Org, UN.

WB, World Bank (2019) Open Data, available at https://datacatalog.worldbank.org/ (accessed 13 September 2019).

WEF, World Economic Forum (2018). The Global Competitiveness Report 2017 2018. Retrieved from: http://www3.weforum.org/docs/GCR2017-2018/05Full Report/TheGlobalCompetitivene ssReport2017\%E2\%80\%932018.pdf.

\title{
Međunarodna financijska uključenost: Višedimenzionalne odrednice pristupa štednji i kreditima
}

\author{
Lilianne Isabel Pavón Cuéllar ${ }^{1}$
}

\begin{abstract}
Sažetak
U ovom radu kvantitativno su utvrđene odrednice dvaju glavnih pokazatelja financijske uključenosti: vlasništvo na štednim računima kreditna dostupnost. Korištenjem dinamičkog panela, ovaj rad potvrđuje da s aspekta ponude, formalna štednja zahtijeva infrastrukturu za pristup tim uslugama, kao i palijativnost asimetričnim informacijama u financijskom sektoru, dok na strani potražnje, presudni su obrazovanje $i$ stabilnost izvora prihoda njegovih potencijalnih korisnika. Da bi se prešlo na sveobuhvatnije financijsko uključivanje uzimanjem formalnog zajma, iako je pristup ovoj infrastrukturi i dalje relevantan, njezin se učinak smanjuje. Stoga nacionalna obrazovna razina i Kreditno informacijska društva dobivaju na važnosti, kao i ranjivost zaposlenosti, što utječe na prihvatljivost $i$ obvezu koja podrazumijeva prezaduženost. Značaj određenih kulturnih obilježja na kreditnom statičkom panelu upozorava da, iako se financijska uključenost može promovirati provjerenim međunarodnim standardima, njezina se učinkovitost ne može odvojiti od društvenog konteksta u kojem se provode.
\end{abstract}

Ključne riječi: financijska uključenost, asimetrične informacije, kulturne osobine, ranjiva zaposlenost

JEL klasifikacija: G2, G18, G21, E2

\footnotetext{
1 Redoviti profesor, Anáhuac University Mexico, Faculty of Business and Economics, Av. Lomas Anáhuac 46, Col. Lomas Anáhuac, Huixquilucan Estado de México, CP 52786, Meksiko. Znanstveni interes: održivi ekonomski rast, društveni kapital i financijska uključenost. Tel.: +525556270210 ext.8601. E-mail: lpavon@anahuac.mx. ORCID: 0000-0002-1410-034X.
} 